\title{
Influence of Wall Material Composition on Microencapsulation Efficiency of Cold Pressed Pumpkin Seed Oil by Freeze-Drying
}

\author{
Zeynep Aksoylu Özbek and Pelin Günç Ergönül* \\ Department of Food Engineering, Turkey \\ *Corresponding author: Pelin Günç Ergönül, Department of Food Engineering, Manisa, Turkey
}

Submission: December 16, 2018; Published: December 20, 2018

\begin{abstract}
The main goal of this research was to investigate the effects of wall materials on microencapsulation efficiency of pumpkin seed oil by freeze-drying Different ratios of maltodextrin (MD), xanthan gum (XG), gum arabic (GA), whey protein concentrate (WPC 80), casein and, lecithin combinations were used as wall materials to encapsulate cold pressed pumpkin seed oil. Microencapsulation efficiency values of microcapsules ranged between 12.36-34.51\%. The maximum microencapsulation efficiency was achieved using maltodextrin, gum arabic, whey protein concentrate, and lecithin combination.
\end{abstract}

\section{Introduction}

Encapsulation is a food preservation method where sensitive compounds, known as "core material", can be entrapped within a matrix that is called "wall material" [1]. Capsules of which sizes range between $3-800 \mu \mathrm{m}$ are called microcapsules, while particle sizes of Nano capsules range between 10-1000nm [2]. The most widely used microencapsulation techniques are spray drying, spray cooling, extrusion, fluidized bed coating, freeze-drying (lyophilization), coacervation, cocrystallization, interfacial or in-situ polymerization $[3,4]$. Although its high production costs, freeze-drying is a unique technology for heat sensitive core materials. The well-known reasons of encapsulation are protection of core material against environmental factors such as oxygen, light or heat and hence, extending the shelf life of product; improvement of core materials' handling and storage properties; controlled release of core materials; and/or masking of off-odour and off-taste [1,5]. Main compounds that need to be encapsulated are flavours, antioxidants, antimicrobials, bioactive peptides, minerals, vitamins, bioactive lipids, probiotics and dietary fibres [6]. Various carbohydrates (starch, cellulose, gum Arabic, carrageenan, alginate, xanthan, chitosan etc.), proteins (whey protein, casein, gluten, gelatin etc.) and lipids (phospholipids, fatty acids, waxes etc.) may be used as wall materials in encapsulation processes [7]. The main advantages of maltodextrins are serving as an efficient barrier against oxidation, neutral taste, low cost, high solubility in water and formation of low viscosity solutions even at high concentrations. However, due to lack of emulsifying capacity of maltodextrins, they should be used in combination with surface active wall materials such as gum arabic $[8,9]$. In encapsulation processes, milk proteins, whey and casein, improve stability of food emulsions by their high film-form ing and emulsifying properties [10]. It should be kept in mind that whey acts as a more effective emulsifier in oil-in-water emulsions than casein and sodium caseinate [11]. Surface active activity of gum arabic is attributed to its low protein content [12]. Nevertheless, its high price and limited availability require its incorporation into other wall materials [13]. Lecithin may be added to wall material combinations to enhance wettability and dispersibility properties of microcapsules containing oil or fat [14].

Pumpkin (Cucurbita pepo subsp. pepo var. Styriaca) seed oil is a specialty oil that contains substantial amounts of unsaturated fatty acids, mainly linoleic and oleic acids, squalene, phytosterols, tocopherols and tocotrienols [15-17]. All of these are accepted as bioactive compounds due to their health promoting properties. However, pumpkin seed oil rich in unsaturated fatty acids is susceptible to oxidation. Microencapsulation of pumpkin seed oil by freeze-drying may protect the oil against environmental conditions and improve the oxidative stability of oil. The objective of this study is to investigate the effects of wall materials on encapsulation efficiency of cold pressed pumpkin seed oil by freeze-drying.

\section{Materials and Methods}

\section{Material}

Pumpkin seeds were purchased from Yürekli Gida San. Tic. Ltd. Şti. (Konya, Turkey). Then, oil of the seeds was obtained by using a Cold-pressing machine (Toper Machine, Izmir, Turkey). The temperature of the machine maintained at $40{ }^{\circ} \mathrm{C}$ during operation. Next, oils were centrifuged (Hettich Universal 32R, Germany) at $4000 \mathrm{rpm}$ for $20 \mathrm{~min}$ at $15{ }^{\circ} \mathrm{C}$. Finally, oils were transferred 
to amber coloured bottles under nitrogen and stored at $4{ }^{\circ} \mathrm{C}$ until further use. Cold pressed pumpkin seed oil with the following physicochemical properties was used as core material: Lovibond R: 39; Lovibond Y: 19 ; refractive index at $20^{\circ} \mathrm{C}$ : 1.45545 ; free fatty acids: $0.31 \%$ oleic acid; iodine value: $101.31 \mathrm{~g} / 100 \mathrm{~g}$; peroxide value: $4.03 \mathrm{meq} 02 / \mathrm{kg}$; total chlorophyll content: $2.86 \mathrm{mg}$ pheophytin a/kg; total carotenoid content: $5.42 \mathrm{mg}$ lutein $/ \mathrm{kg}$, DPPH-scavenging activity: $5.50 \mathrm{mM}$ Trolox equivalent $/ 100 \mathrm{~g}$; total phenolic content: $13.25 \mathrm{mg}$ gallic acid equivalent $/ 100 \mathrm{~g}$; $37.03 \%$ oleic acid, $43.67 \%$ linoleic acid, $11.11 \%$ palmitic acid, $6.70 \%$ stearic acid; $180.89 \mathrm{mg} \gamma$-tocopherol/100g and $91.30 \mathrm{mg} \alpha$-tocopherol/100g.

\section{Emulsion preparation}

The wall materials (MD, XG, GA, WPC 80, casein and, lecithin) were selected according the previous similar studies. The composition of each run was summarized in Table 1. Wall materials were separately dissolved in distilled water by mixing with magnetic stirrer (Wisd Wise Stir MSH-20A, Germany) at 1500rpm for $10 \mathrm{~min}$. Then, each wall material solution was combined in a stainless-steel beaker and pumpkin seed oil was added to this mixture. Emulsions were formed using a rotor stator homogenizer (Velp 0V-5, Italy) at $22.000 \mathrm{rpm}$ for $7 \mathrm{~min}$. Obtained emulsions were frozen in petri dishes at $-25^{\circ} \mathrm{C}$ for $24 \mathrm{~h}$.

Table 1: Compositions of emulsions.

\begin{tabular}{|c|c|c|c|c|c|c|c|}
\hline Run & MD (g) & XG (g) & GA (g) & WPC 80 (g) & Casein (g) & Lecithin (g) & Pumpkin Seed Oil (g) \\
\hline Run-1 & 0.8 & 0.5 & - & 0.2 & - & - & 1 \\
\hline Run-2 & 0.8 & 0.5 & - & - & 0.2 & - & 1 \\
\hline Run-3 & 0.8 & - & 0.5 & 0.2 & - & - & 1 \\
\hline Run-4 & 0.8 & - & 0.5 & - & 0.2 & 0.002 & 1 \\
\hline Run-5 & 0.8 & - & 0.5 & 0.2 & - & 0.002 & 1 \\
\hline Run-6 & 1.6 & - & 0.5 & 0.2 & - & 0.002 & 1 \\
\hline Run-7 & 0.8 & - & 0.5 & 0.8 & - & & 1 \\
\hline
\end{tabular}

\section{Microencapsulation by freeze-drying}

Freeze-drying process was performed in a laboratory scale freeze dryer (Christ Alpha 2-4 LD, Germany) operating at $-80{ }^{\circ} \mathrm{C}$ for $48 \mathrm{~h}$. After freeze-drying, pellets were ground into powder using a knife mill (Retsch Grindomix GM200, Germany).

\section{Encapsulation efficiency}

Total and surface oil fractions of microcapsules were extracted according to the methods suggested by Velasco et al. [18]. Encapsulation efficiency was calculated using the following equation:

$$
\text { Encapsulation efficiency }(\%)=\left(\frac{\text { Total oil }- \text { Surface oil }}{\text { Total oil }}\right) * 100
$$

\section{Statistical analysis}

Experiments were performed in duplicate. Data were subjected to one-way analysis of variance (ANOVA) in SAS Ver 8.2 and compared by Fisher's LSD test method at $\mathrm{p}<0.05$. Results were presented as mean \pm standard deviation.

\section{Results and Discussion}

Table 2: Free oil contents and microencapsulation efficiency values of runs.

\begin{tabular}{|c|c|c|}
\hline Run & Surface Oil (\%) & Microencapsulation Efficiency (\%) \\
\hline Run-1 & $24.20 \pm 0.91^{\mathrm{a}}$ & $16.32 \pm 1.64^{\mathrm{d}}$ \\
\hline Run-2 & $24.29 \pm 0.60^{\mathrm{a}}$ & $12.36 \pm 0.69^{\mathrm{e}}$ \\
\hline Run-3 & $16.35 \pm 0.63^{\mathrm{c}}$ & $33.62 \pm 0.72^{\mathrm{a}}$ \\
\hline Run-4 & $19.52 \pm 0.98^{\mathrm{b}}$ & $28.67 \pm 0.7^{3} \mathrm{~b}$ \\
\hline Run-5 & $15.59 \pm 0.30^{\mathrm{b}}$ & $34.51 \pm 0.51^{\mathrm{a}}$ \\
\hline
\end{tabular}

\begin{tabular}{|l|l|l|}
\hline Run-6 & $21.21 \pm 0.41^{\mathrm{b}}$ & $19.54 \pm 0.55^{\mathrm{c}}$ \\
\hline Run-7 & $20.22 \pm 0.71^{\mathrm{b}}$ & $22.04 \pm 0.51^{\mathrm{c}}$ \\
\hline
\end{tabular}

Microencapsulation efficiency is the best indicator of the success of any encapsulation process. As the amount of oil found on the surface of microcapsule decreases, the amount of encapsulated oil and correspondingly, encapsulation efficiency increases. Surface oil contents of the microcapsules and microencapsulation efficiency of each run were given in Table 2. Microencapsulation efficiency of runs ranged between 12.36-34.51\%. Higher microencapsulation efficiency values by freeze-drying were reported for fish oil (29.40-81.60\%) [19]; flaxseed oil (32.68-59.63\%) [20]; olive oil (36.90-69.09\%) [21], and rosemary essential oil (69.90-96.14\%) [22] previously. Although all of these oils were encapsulated using freeze-drying, extremely different microencapsulation efficiency values reported by various researchers may be explained by various type and ratio of wall materials used; ratio of core-to-wall material and type of homogenizer (high shear rotor-stator homogenizer, ultrasonic homogenizer, microfluidizer, high pressure homogenizer). Effects of wall material composition on free oil amounts and microencapsulation efficiency of microcapsules were statistically significant $(\mathrm{p}<0.05)$. Due to its high viscosity, xanthan gum decreased the efficiency of mixing and homogenization of emulsions. Consequently, microcapsules containing xanthan gum (Run-1 and Run-2) had lower microencapsulation efficiency values than the corresponding microcapsules with gum arabic (Run-3 and Run-4). Moreover, surface active characteristic of gum arabic may contribute to higher stability of pumpkin seed oil-in-water emulsions. A stable emulsion inhibits oil droplet aggregation during freezing and provides increased microencapsulation efficiency. Addition of lecithin into 
emulsion consisting of maltodextrin, gum arabic and whey protein concentrate (Run-3) caused a slight and statistically insignificant ( $>0.05)$ increase in microencapsulation efficiency. Substitution casein for whey protein concentrate decreased microencapsulation efficiency of freeze dried microcapsules. However, our results contrast with the findings of Fäldt \& Bergenståhl [23], who reported better encapsulation ability of sodium caseinate than whey protein for soybean oil microencapsulation [23]. Sheu \& Rosenberg [24] suggested that interaction between carbohydrate (maltodextrin) and protein (whey) may alter the emulsification properties of emulsions [24]. The changes observed when maltodextrin (Run-6) or whey protein concentrate (Run-7) amounts increased in the emulsion may be attributed to strength of protein-carbohydrate interactions explained by Sheu \& Rosenberg [24]. Moreover, differences between surface oil contents and microencapsulation efficiency of our protein-stabilized emulsions may be affected by instabilities like droplet coalescence occurred during freezing of emulsions [25]. Results obtained through our study verified the use of wall material combinations containing different ratios of maltodextrin, xanthan gum, gum arabic, casein, whey protein concentrate and lecithin for encapsulation of cold pressed pumpkin seed oil. Among all wall material combinations produced in this study, blend of maltodextrin + gum Arabic + whey protein concentrate + lecithin (Run-5) yielded the maximum encapsulation efficiency (34.51\%).

\section{Conclusion}

This study demonstrated the applicability of different combinations of selected wall materials for cold pressed pumpkin seed oil microencapsulation by freeze-drying. Lower encapsulation efficiency values may be improved by optimizing concentration of each component serving as wall material and optimizing of core-to-wall material ratio or determination of suitable emulsion freezing conditions. Further studies will focus on improvement of microencapsulation efficiency of microcapsules and investigation of these microcapsules in terms of oxidative parameters such as peroxide value, p-alinidine value and TOTOX value. Moreover, another research could also be designed to investigate the effects of encapsulation process parameters on biologically active compounds of oils.

\section{References}

1. Zuidam NJ, Shimoni E (2010) Overview of microencapsulates for use in food products or processes and methods to make them. In: Zuidam NJ, Nedovic VA (Eds.), Encapsulation Technologies for Active Food Ingredients and Food Processing. Springer, New York, USA, pp. 3-29.

2. Kwak HS (2014) Overview of nano and microencapsulation for foods. In: Kwak HS (Ed.), Nano and Microencapsulation for Foods Wiley-Blackwell, West Sussex, UK, pp. 1-14.

3. Jyothi N, NagaVP, Muthu P, Suhas NS, Sakarkar K, et al. (2010) Microencapsulation techniques, factors influencing encapsulation efficiency. J Microencapsul 27(3): 187-197.

4. Ghosh SK (2006) Functional coatings and microencapsulation: A general perspective. In Ghosh SK (Ed.), Functional Coatings. Wiley-VCH Verlag GmbH \& Co. KGaA, Weinheim, FRG, Germany, pp. 1-28.
5. Sobel R, Versic R, Gaonkar AG (2014) Introduction to microencapsulation and controlled delivery in foods. In: Gaonkar AG, Vasisht N, Khare AR, Sobel R (Eds.), Microencapsulation in the Food Industry. Academic Press, San Diego, CA, USA, pp. 3-12

6. McClements DJ (2012) Requirements for food ingredient and nutraceutical delivery systems. In: Garti N, McClements DJ (Eds.), Encapsulation Technologies and Delivery Systems for Food Ingredients and Nutraceuticals, Woodhead Publishing Limited, Cambridge, UK, pp. 3-18.

7. Wandrey C, Bartkowiak A, Harding SE (2010) Materials for encapsulation. In: Zuidam NJ, Nedović V (Eds.), Encapsulation technologies for active food ingredients and food processing. Springer, New York, USA, pp. 31100 .

8. Gibbs BF, Kermasha S, Alli I, Mulligan CN (1999) Encapsulation in the food industry: A review. Int J Food Sci Nutr 50(3): 213-224.

9. Martínez ML, Curti MI, Roccia P, Llabot JM, Penci MC, et al. (2015) Oxidative stability of walnut (Juglans regia L.) and chia (Salvia hispanica L.) oils microencapsulated by spray drying. Powder Technol 270: 271277.

10. Augustin MA, Oliver CM (2014) Use of milk proteins for encapsulation of food ingredients. In: Gaonkar AG, Vasisht N, Khare AR, Sobel R (Eds.), Microencapsulation in the Food Industry: A Practical Implementation Guide, Academic Press, San Diego, CA, USA, pp. 211-226.

11. Boland M (2011) Whey proteins. In: Phillips GO, Williams PA (Eds.), Handbook of Food Proteins, Woodhead Publishing, Cambridge, UK, pp. 30-55.

12. Gharsallaoui A, Roudaut G, Chambin O, Voilley A, Saurel R (2007) Applications of spray-drying in microencapsulation of food ingredients: An overview. Food Res Int 40(9): 1107-1121

13. Carneiro HCF, Tonon RV, Grosso CRF, Hubinger MD (2013) Encapsulation efficiency and oxidative stability of flaxseed oil microencapsulated by spray drying using different combinations of wall materials. J Food Eng 115(4): 443-451.

14. Barbosa CGV, Ortega RE, Juliano P, Yan H (2005) Food powders - physical properties, processing, and functionality. Kluwer Academic/Plenum Publishers, New York, USA,

15. Procida G, Stancher B, Cateni F, Zacchigna M (2013) Chemical composition and functional characterization of commercial pumpkin seed oil. J Sci Food Agric 93(5): 1035-1041.

16. Stevenson DG, Eller FJ, Wang L, Jane JL, Wang T, et al. (2007) Oil and tocopherol content and composition of pumpkin seed oil in 12 cultivars. J Agric Food Chem 55(10): 4005-4013.

17. Naziri E, Mitić MN, Tsimidou MZ (2016) Contribution of tocopherols and squalene to the oxidative stability of cold-pressed pumkin seed oil (Cucurbita pepo L.). Eur J Lipid Sci Technol 118(6): 898-905.

18. Velasco J, Holgado F, Dobarganes C, Márquez RG (2009) Antioxidant activity of added phenolic compounds in freeze-dried microencapsulated sunflower oil. J Am Oil Chem Soc 86(5): 445-452.

19. Holgado F, Márquez RG, Dobarganes C, Velasco J (2013) Influence of homogenization conditions and drying method on physicochemical properties of dehydrated emulsions containing different solid components. Int J Food Sci Technol 48(7): 1498-1508.

20. Quispe CS, Saldaña MDA, Temelli F (2011) Microencapsulation of flax oil with zein using spray and freeze drying. LWT - Food Sci Technol 44(9): 1880-1887.

21. Calvo P, Castaño ÁL, Lozano M, González GD (2012) Influence of the microencapsulation on the quality parameters and shelf-life of extravirgin olive oil encapsulated in the presence of BHT and different capsule wall components. Food Res Int 45(1): 256-261. 
22. Turasan H, Sahin S, Sumnu G (2015) Encapsulation of rosemary essential oil. LWT - Food Sci Technol 64(1): 112-119.

23. Fäldt P, Bergenståhl B (1996) Spray-dried whey protein/lactose/ soybean oil emulsions 1. Surface composition and particle structure. Food Hydrocoll 10(4): 421-429.
24. Sheu TY, Rosenberg M (1995) Microencapsulation by spray drying ethyl caprylate in whey protein and carbohydrate wall systems. J Food Sci 60(1): 98-103.

25. McClements DJ (2004) Protein-stabilized emulsions. Curr Opin Colloid Interface Sci 9(5): 305-313.

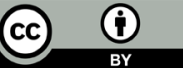

Creative Commons Attribution 4.0 International License

For possible submissions Click Here

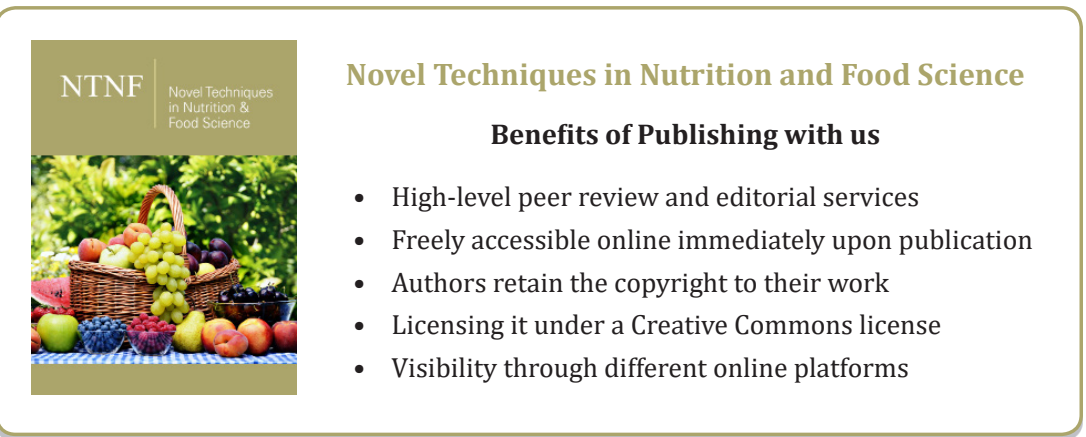

